OPEN ACCESS

Edited by:

Mingxiong $\mathrm{He}$,

Biogas Institute of Ministry of Agriculture (CAAS), China

Reviewed by:

Koshy Philip,

University of Malaya, Malaysia

Guodong Luan,

Qingdao Institute of Bioenergy and Bioprocess Technology (CAS), China

*Correspondence:

Tomoyuki Kosaka

tkosaka@yamaguchi-u.ac.jp

Specialty section:

This article was submitted to

Microbiotechnology,

a section of the journal

Frontiers in Microbiology

Received: 08 October 2019

Accepted: 09 March 2020

Published: 31 March 2020

Citation:

Kosaka T, Nishioka A, Sakurada T,

Miura $K$, Anggarini $S$ and Yamada $M$

(2020) Enhancement of Thermal

Resistance by Metal lons

in Thermotolerant Zymomonas

mobilis TISTR 548.

Front. Microbiol. 11:502.

doi: 10.3389/fmicb.2020.00502

\title{
Enhancement of Thermal Resistance by Metal lons in Thermotolerant Zymomonas mobilis TISTR 548
}

\section{Tomoyuki Kosaka ${ }^{1,2 *}$, Aya Nishioka1, Tomoko Sakurada ${ }^{1}$, Kento Miura ${ }^{3}$, Sakunda Anggarini' ${ }^{1}$ and Mamoru Yamada ${ }^{1,2}$}

${ }^{1}$ Graduate School of Science and Technology for Innovation, Yamaguchi University, Yamaguchi, Japan, ${ }^{2}$ Research Center for Thermotolerant Microbial Resources, Yamaguchi University, Yamaguchi, Japan, ${ }^{3}$ Faculty of Agriculture, Yamaguchi University, Yamaguchi, Japan

The thermal resistance of fermenting microbes is a key characteristic of stable fermentation at high temperatures. Therefore, the effects of various metal ions on the growth of Zymomonas mobilis TISTR 548, a thermotolerant ethanologenic bacterium, at a critical high temperature $(\mathrm{CHT})$ were examined. Addition of $\mathrm{Mg}^{2+}$ and $\mathrm{K}^{+}$increased $\mathrm{CHT}$ by $1^{\circ} \mathrm{C}$, but the effects of the addition of $\mathrm{Mn}^{2+}, \mathrm{Ni}^{2+}, \mathrm{Co}^{2+}, \mathrm{Al}^{3+}, \mathrm{Fe}^{3+}$, and $\mathrm{Zn}^{2+}$ on $\mathrm{CHT}$ were negligible. To understand the physiological functions associated with the addition of $\mathrm{Mg}^{2+}$ or $\mathrm{K}^{+}$, cell morphology, intracellular reactive oxygen species (ROS) level, and ethanol productivity were investigated at $39^{\circ} \mathrm{C}$ (i.e., above $\mathrm{CHT}$ ). Cell elongation was repressed by $\mathrm{Mg}^{2+}$, but not by $\mathrm{K}^{+}$. Addition of both metals reduced intracellular ROS level, with only $\mathrm{K}^{+}$showing the highest reduction strength, followed by both metals and only $\mathrm{Mg}^{2+}$. Additionally, ethanol productivity was recovered with the addition of both metals. Moreover, the addition of $\mathrm{Mg}^{2+}$ or $\mathrm{K}^{+}$at a non-permissive temperature in 26 thermosensitive, single gene-disrupted mutants of $Z$. mobilis TISTR 548 revealed that several mutants showed metal ion-specific growth improvement. Remarkably, $\mathrm{K}^{+}$repressed growth of two mutants. These results suggest that $\mathrm{K}^{+}$ and $\mathrm{Mg}^{2+}$ enhance cell growth at $\mathrm{CHT}$ via different mechanisms, which involve the maintenance of low intracellular ROS levels.

Keywords: Zymomonas, thermotolerance, metals, magnesium, potassium

\section{INTRODUCTION}

Recently, bioethanol has gained attention as an alternative to fossil fuel because as a carbonneutral fuel, it can potentially delay the progress of global warming (Hahn-Hägerdal et al., 2006; Chisti, 2008). However, industrial scale bioethanol production requires a more costeffective process to be economically competitive. High-temperature fermentation (HTF; which enables fermentation at a temperature $5-10^{\circ} \mathrm{C}$ higher than that used in the conventional process) may reduce (1) cooling cost, (2) running cost at the simultaneous saccharification and fermentation stage, and (3) contamination risks (Abdel-Banat et al., 2010; Kosaka et al., 2018). Bioethanol production by HTF requires high-efficiency ethanol production and thermotolerant microorganisms. Zymomonas mobilis, a Gram-negative, facultative, anaerobic bacterium, performs high-speed ethanol production (He et al., 2014) compared with the conventional ethanol producer Saccharomyces cerevisiae, whose cultivation temperature of $>35^{\circ} \mathrm{C}$ is not permissible for yeast growth (Aldiguier et al., 2004). Z. mobilis, which uses the Entner-Doudoroff pathway and an incomplete TCA cycle, is facultatively anaerobic and requires no oxygen for its growth; conversely, 
it assimilates glucose, fructose, and sucrose as the sole carbon sources (Panesar et al., 2006; He et al., 2014). We focused on $Z$. mobilis TISTR 548, one of the thermotolerant Z. mobilis strains that grew at $39^{\circ} \mathrm{C}$ (Sootsuwan et al., 2007), and developed thermotolerant mutants by thermal adaptation enhancement of its critical high temperature (CHT), an upper limit for survival, up to $2^{\circ} \mathrm{C}$ (Matsushita et al., 2016; Kosaka et al., 2019). We subsequently used this mutant strain with HTF using a model fermentation and distillation system to reveal the effectiveness of this method and bioethanol productivity by HTF with Z. mobilis (Murata et al., 2015).

Metal ions enhance the growth of ethanologenic microorganisms at $\mathrm{CHT}$. Microorganisms require several ions as essential metals for the normal function and homeostasis of a wide range of cellular proteins (Reid et al., 2009), but these ions are toxic at high concentrations (Gadd, 1992). Among these ions, only $\mathrm{Mg}^{2+}$ has been reported to enhance thermotolerance in Z. mobilis strains (Thanonkeo et al., 2007). Moreover, $\mathrm{Mg}^{2+}$ helped recover thermosensitive mutants of $Z$. mobilis TISTR 548, in which genes for membrane stabilization or membrane formation were disrupted, suggesting that at $\mathrm{CHT}, \mathrm{Mg}^{2+}$ stabilizes membrane structure and protects cells from heat (Charoensuk et al., 2017). $\mathrm{Mg}^{2+}$ also stabilizes the outer membrane (OM) structure, at least of lipopolysaccharide (LPS), of cells by divalent cation crossbridging (bridging action) in Gram-positive bacteria (Nikaido, 2003). Studies on several microorganisms, particularly Escherichia coli (Murata et al., 2011) and Lactobacillus strains (Yang et al., 2017), have revealed the thermotolerance-enhancing effect of $\mathrm{Mg}^{2+}$. However, although the enhancing effects of $\mathrm{K}^{+}$and $\mathrm{Ca}^{2+}$ on $\mathrm{S}$. cerevisiae (Lam et al., 2014) and lactic acid bacteria (Huang and Chen, 2013), respectively, have been reported, there is no report about the enhancement effects of these and other metals on Z. mobilis growth at CHT. This evidence suggests that the concentration of several metals in a fermentation medium is important for efficient HTF for bioethanol production. However, the effect of a wide range of metals on $Z$. mobilis TISTR 548 at CHT is yet to be investigated. Besides, the mechanism underlying the effects of these metals, such as $\mathrm{Mg}^{2+}$, on cell physiology at CHT remains unclear.

In this study, the effects of metal ions, i.e., $\mathrm{Mn}^{2+}, \mathrm{Ni}^{2+}$, $\mathrm{Co}^{2+}, \mathrm{Al}^{3+}, \mathrm{Fe}^{3+}, \mathrm{Zn}^{2+}, \mathrm{Mg}^{2+}, \mathrm{K}^{+}$, and $\mathrm{Ca}^{2+}$, on Z. mobilis TISTR 548 growth at CHT were observed. Moreover, the effects of $\mathrm{Mg}^{2+}$ and $\mathrm{K}^{+}$(these metals enhanced growth at CHT) on the physiology of Z. mobilis TISTR 548 and its thermosensitive mutants were investigated.

\section{MATERIALS AND METHODS}

\section{Bacterial Strains, Media, and Cultivation Conditions}

The bacterial strains used in this study are listed in Table $\mathbf{1}$. To grow Z. mobilis, a preculture was prepared in $2 \mathrm{~mL}$ of YPD medium ( $0.3 \%$ yeast extract, $0.5 \%$ peptone, and $3 \%$ glucose) and incubated overnight at $30^{\circ} \mathrm{C}$. The overnight culture was subsequently inoculated into fresh YPD medium at an
$\mathrm{OD}_{550}$ of 0.05 . Cultivation was performed under non-shaking (static) conditions.

\section{Examination of the Effects of Various Materials on Cell Growth}

To compare the effects of additional reagents, cells were subjected to two-step cultivation (Kosaka et al., 2019) at the same temperature to observe the effect of temperature or additional reagents. Two-step cultivation can simply determine the temperature-upper limit for the survival of cells because when the first culture is performed at a temperature just above a CHT, cells cannot grow in the second culture at the same temperature (Kosaka et al., 2019). In the first culture, the OD value of the culture increases even at a temperature over CHT because of cell elongation. The CHT of Z. mobilis TISTR 548 has been determined to be $38^{\circ} \mathrm{C}$ by this method (Kosaka et al., 2019). Reagents were added to a medium at the desired condition before each inoculation. Briefly, the first cultivation was performed until the culture attained a late log phase at a temperature around a putative CHT; then, a portion of the first culture was transferred into a fresh medium at an $\mathrm{OD}_{550}$ of 0.05 and cultured at the same temperature. All metals tested were obtained in the form of chloride salts.

TABLE 1 | List of Zymomonas mobilis strains used in this study.

\begin{tabular}{|c|c|c|}
\hline Strain & Genotype & Reference or source \\
\hline TISTR 548 & & TISTR collections \\
\hline TC01 & TISTR 548 (ZZ6_0707:Tn10) & Charoensuk et al., 2017 \\
\hline TC03 & TISTR 548 (ZZ6_1376:Tn10) & Charoensuk et al., 2017 \\
\hline TE12 & TISTR 548 (ZZ6_1146:Tn10) & Charoensuk et al., 2017 \\
\hline C12-36 & TISTR 548 (ZZ6_1551:Tn10) & Charoensuk et al., 2017 \\
\hline C11-44 & TISTR 548 (ZZ6_1046:Tn10) & Charoensuk et al., 2017 \\
\hline C13-36 & TISTR 548 (ZZ6_1210:Tn10) & Charoensuk et al., 2017 \\
\hline TC04 & TISTR 548 (ZZ6_0923:Tn10) & Charoensuk et al., 2017 \\
\hline $1-2$ & TISTR 548 (ZZ6_1043:Tn10) & Charoensuk et al., 2017 \\
\hline $3-24$ & TISTR 548 (ZZ6_0929:Tn10) & Charoensuk et al., 2017 \\
\hline $\mathrm{TC} 14$ & TISTR 548 (ZZ6_0158:Tn10) & Charoensuk et al., 2017 \\
\hline C31-23 & TISTR 548 (ZZ6_1254:Tn10) & Charoensuk et al., 2017 \\
\hline TC15 & TISTR 548 (ZZ6_1477:Tn10) & Charoensuk et al., 2017 \\
\hline F32 & TISTR 548 (ZZ6_0616:Tn10) & Charoensuk et al., 2017 \\
\hline C12-43 & TISTR 548 (ZZ6_0934:Tn10) & Charoensuk et al., 2017 \\
\hline TC10 & TISTR 548 (ZZ6_0681:Tn10) & Charoensuk et al., 2017 \\
\hline C12-44 & TISTR 548 (ZZ6_0023:Tn10) & Charoensuk et al., 2017 \\
\hline $\mathrm{C} 21-17$ & TISTR 548 (ZZ6_1659:Tn10) & Charoensuk et al., 2017 \\
\hline TC05 & TISTR 548 (ZZ6_0980:Tn10) & Charoensuk et al., 2017 \\
\hline $\mathrm{TC} 12$ & TISTR 548 (ZZ6_0702:Tn10) & Charoensuk et al., 2017 \\
\hline TE19 & TISTR 548 (ZZ6_0979:Tn10) & Charoensuk et al., 2017 \\
\hline C31-15 & TISTR 548 (ZZ6_0019:Tn10) & Charoensuk et al., 2017 \\
\hline TC11 & TISTR 548 (ZZ6_0840:Tn10) & Charoensuk et al., 2017 \\
\hline C12-37 & TISTR 548 (ZZ6_0962:Tn10) & Charoensuk et al., 2017 \\
\hline TC09 & TISTR 548 (ZZ6_0541:Tn10) & Charoensuk et al., 2017 \\
\hline $\mathrm{TC} 13$ & TISTR 548 (ZZ6_0861:Tn10) & Charoensuk et al., 2017 \\
\hline $1-10$ & TISTR 548 (ZZ6_1289:Tn10) & Charoensuk et al., 2017 \\
\hline
\end{tabular}




\section{Cell Morphology}

Cell morphology was observed using phase-contrast microscopy (E6F-RFK-1, Nikon, Tokyo, Japan). In total, 100 cells were randomly selected on microphotographs, and their length was measured using ImageJ (Schneider et al., 2012).

\section{Intracellular Reactive Oxygen Species Level}

Zymomonas mobilis TISTR 548 cells were grown on YPD medium at $39^{\circ} \mathrm{C}$. At $12 \mathrm{~h}, 5 \mu \mathrm{M} \mathrm{H}_{2}$ DCFDA was added to the first culture, and further cultivation was performed at $39^{\circ} \mathrm{C}$ for $30 \mathrm{~min}$. Then, cells were harvested by low-speed centrifugation and washed once with phosphate-buffered saline $[130 \mathrm{mM} \mathrm{NaCl}$, $10.8 \mathrm{mM} \mathrm{Na}_{2} \mathrm{HPO}_{4}, 4.2 \mathrm{mM} \mathrm{NaH}_{2} \mathrm{PO}_{4}$ (pH 7.2)]. The washed cells were disrupted by sonication for 30 min using an ultrasonic cell disruptor (Bioruptor; Cosmo Bio, Tokyo, Japan) and subjected to low-speed centrifugation. Supernatant fluorescence was measured using a microplate reader (POWERSCAN ${ }^{\circledR} \mathrm{HT}$; BioTek Instruments, Inc., Winooski, VT, United States). Protein concentration was determined using the Lowry method (Dulley and Grieve, 1975). The result obtained for intracellular reactive oxygen species (ROS) levels is expressed as fluorescence intensity per protein concentration, and the ratio of the number of cells grown in the presence of a metal ion to that of cells grown in its absence was estimated and expressed as percentage.

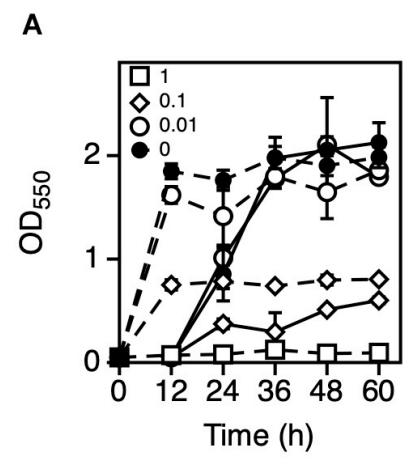

E

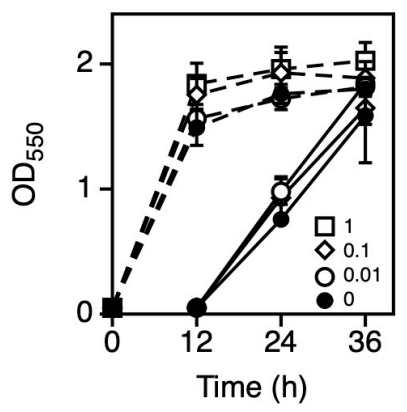

I

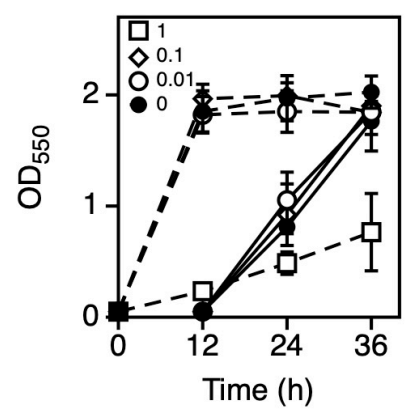

B

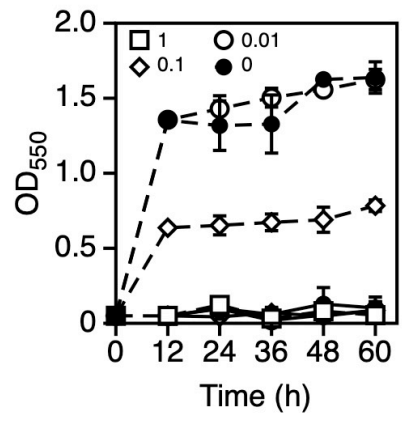

$\mathbf{F}$

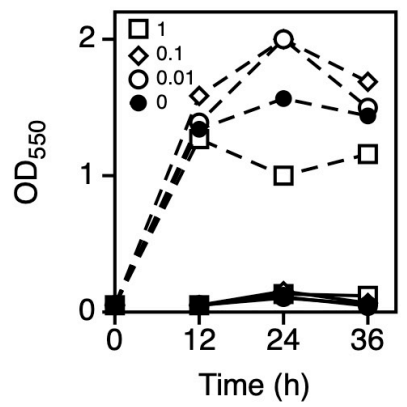

J

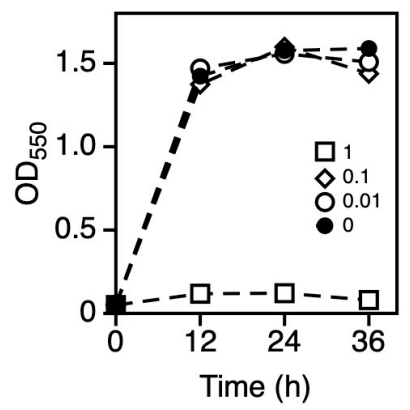

C

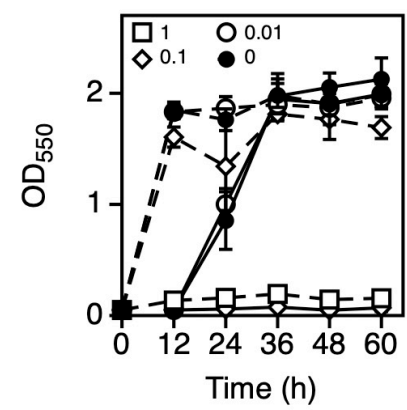

G

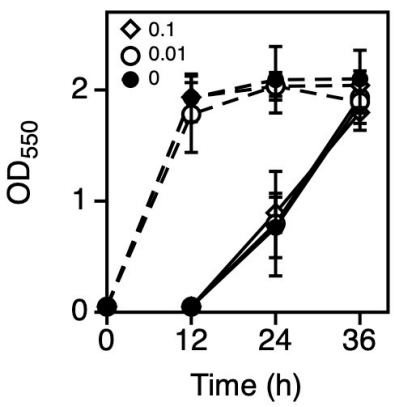

K

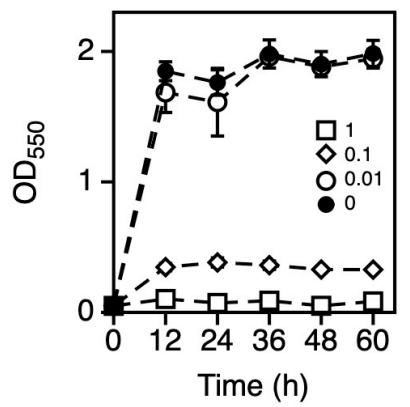

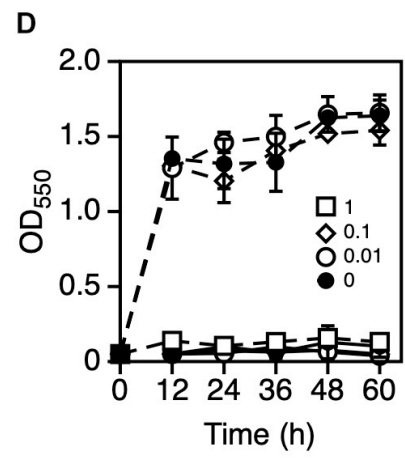

H

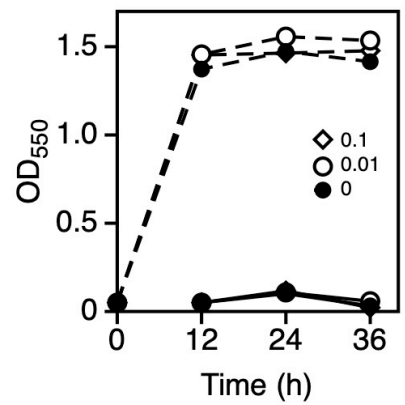

L

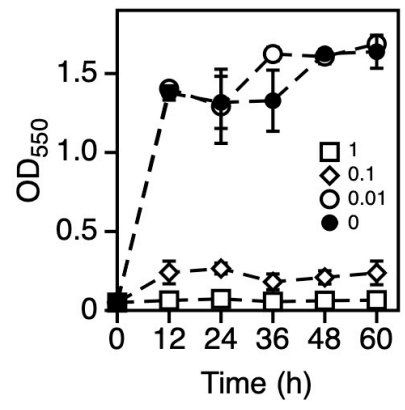

FIGURE 1 | Effects of various metal ions on the two-step cultivation of Zymomonas mobilis TISTR 548. Cells were cultivated in YPD medium at $38^{\circ} \mathrm{C}$ with different concentrations of $\mathrm{NiCl}_{2}$ (A), $\mathrm{ZnCl}_{2}$ (C), $\mathrm{FeCl}_{3}$ (E), $\mathrm{AlCl}_{3}$ (G), $\mathrm{MnCl}_{2}$ (I), or $\mathrm{CoCl}_{2}$ (K) and at $39^{\circ} \mathrm{C}$ with $\mathrm{NiCl}_{2}(\mathbf{B}), \mathrm{ZnCl}_{2}$ (D), $\mathrm{FeCl}_{3}$ (F), $\mathrm{AlCl}_{3}$ (H), $\mathrm{MnCl}_{2}$ (J), or $\mathrm{CoCl}_{2}$ (L) under a static condition. These symbols indicate the means of three replicates, and error bars indicate standard deviations: closed circle, control ( 0 mM); open circle, $0.01 \mathrm{mM}$; open diamond, $0.1 \mathrm{mM}$; and open square, $1.0 \mathrm{mM}$. Dotted and solid lines indicate the OD values of the first and second stages of cultivation, respectively. 


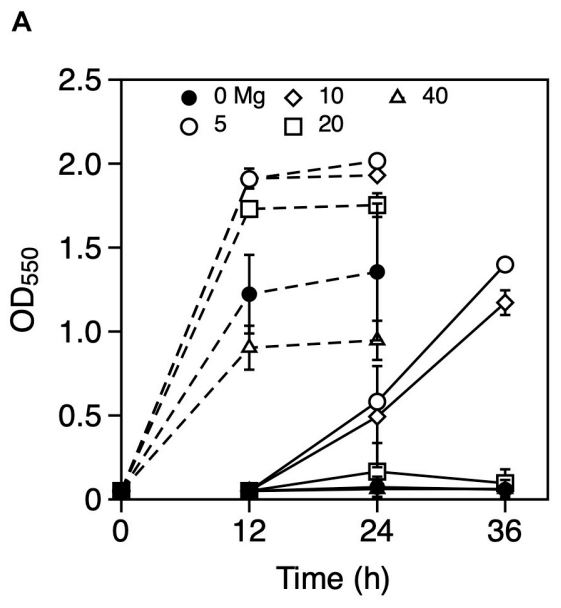

C

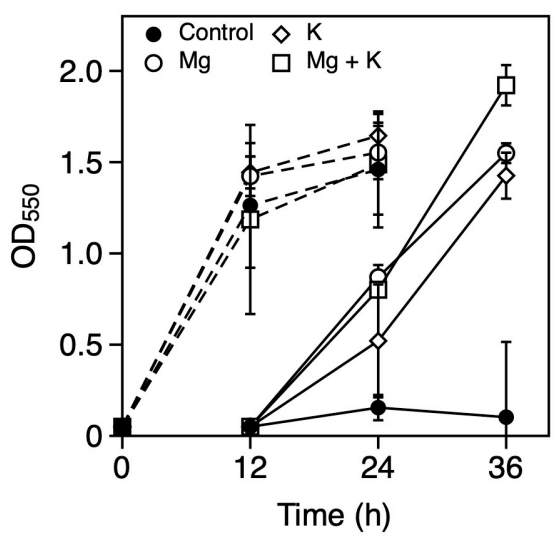

B

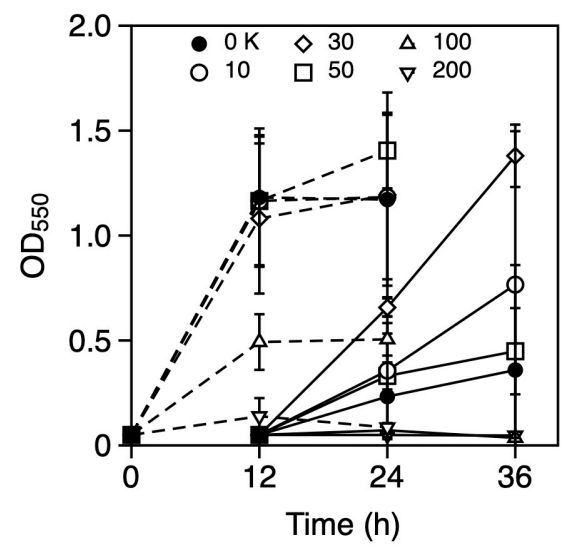

D

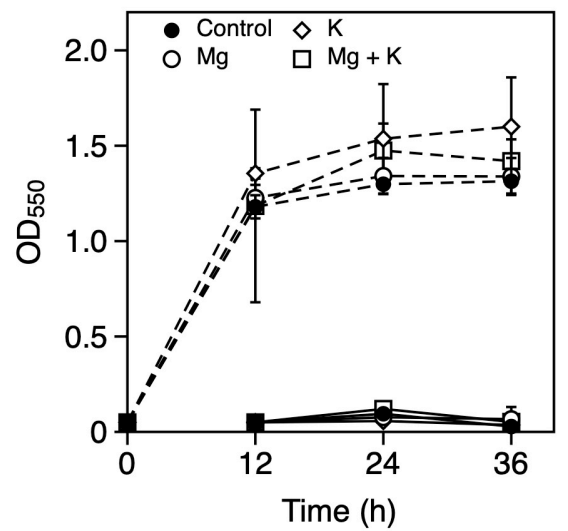

FIGURE 2 | Effects of $\mathrm{Mg}^{2+}$ and $\mathrm{K}^{+}$on the growth of Zymomonas mobilis TISTR 548 at critical high temperatures. Cells were cultivated in YPD medium with several concentrations of $\mathrm{MgCl}_{2}$ (A: closed circle, $0 \mathrm{mM}$; open circle, $5 \mathrm{mM}$; open diamond, $10 \mathrm{mM}$; open square, $20 \mathrm{mM}$; and open triangle, $40 \mathrm{mM}$ ) and $\mathrm{KCl}(\mathbf{B}$ : closed circle, control, $0 \mathrm{mM}$; open circle, $10 \mathrm{mM}$; open diamond, $20 \mathrm{mM}$; open square, $50 \mathrm{mM}$; open triangle up, $100 \mathrm{mM}$; and open triangle down, $200 \mathrm{mM}$ ) at $39^{\circ} \mathrm{C}$ under a static condition. At $39^{\circ} \mathrm{C}$ (C) and $39.5^{\circ} \mathrm{C}$ (D), $5 \mathrm{mM} \mathrm{MgCl}_{2}$ (open circle), $30 \mathrm{mM} \mathrm{KCl}$ (open diamond), and a combination of these metals (open square), were added, and two-step cultivation was performed. Values and error bars represent means and standard deviations, respectively, for triplicate cultures.

\section{Ethanol Concentration}

Ethanol concentration was analyzed using a gas chromatograph (GC-2014, Shimadzu, Kyoto, Japan) equipped with a flame ionization detector and Gaskuropack 54-packed glass column (60/80 mesh; GL Science, Tokyo, Japan); nitrogen was used as a carrier gas (flow rate, $35 \mathrm{~mL} / \mathrm{min}$ ). Operating temperatures were as follows: injection temperature, $200^{\circ} \mathrm{C}$; column temperature, $180^{\circ} \mathrm{C}$; and detector temperature, $200^{\circ} \mathrm{C}$.

\section{RESULTS}

\section{Effects of Metal lons on Z. mobilis TISTR 548 Growth at CHT}

To explore the metal ions that enhance Z. mobilis TISTR 548 growth at putative $\mathrm{CHT}$, the growth levels with and without the addition of $\mathrm{Ni}^{2+}, \mathrm{Zn}^{2+}, \mathrm{Fe}^{3+}, \mathrm{Al}^{3+}, \mathrm{Mn}^{2+}, \mathrm{Co}^{2+}, \mathrm{Mg}^{2+}$, and $\mathrm{K}^{+}$were compared. The effect of the addition of metal ions was evaluated with two-step cultivation, wherein only viable and culturable cells grow, whereas dead or viable but non-culturable cells do not grow in fresh medium at the second cultivation (Kosaka et al., 2019). At $38^{\circ} \mathrm{C}$ and $39^{\circ} \mathrm{C}$, the growth level under the conditions of $0.01 \mathrm{mM} \mathrm{NiCl}_{2}$, $\mathrm{ZnCl}_{2}, \mathrm{FeCl}_{3}, \mathrm{AlCl}_{3}, \mathrm{MnCl}_{2}$, and $\mathrm{CoCl}_{2}$ was the same as that without the addition of metal ions (Figure 1). On the contrary, the addition of $>0.1 \mathrm{mM} \mathrm{NiCl}_{2}$ and $\mathrm{CoCl}_{2}$ led to a lower growth level than no addition of metal ions at the first stage of cultivation (Figures 1A,B,K,L). Similarly, the growth level following the addition of $\mathrm{ZnCl}_{2}$ and $\mathrm{MnCl}_{2}$ was lower at $1 \mathrm{mM}$ (Figures $\mathbf{1 C}, \mathbf{D}, \mathbf{I}, \mathbf{J})$. The growth trend did not change distinctly between 38 and $39^{\circ} \mathrm{C}$ (Figure 1). Ten millimolar $\mathrm{CaCl}_{2}$ or $10 \mathrm{mM} \mathrm{NaCl}$ suppressed growth in the second step of Z. mobilis TISTR 548 cultivation at $38^{\circ} \mathrm{C}$ (data not shown). On the other hand, when $\mathrm{MgCl}_{2}$ and $\mathrm{KCl}$ were added to the medium, there was a $1^{\circ}$ higher growth than there was without adding metals even at $39^{\circ} \mathrm{C}$ (Figures $2 \mathbf{A}-\mathbf{C}$ ). At $39.5^{\circ} \mathrm{C}$, there was negligible growth in the presence of $\mathrm{MgCl}_{2}$ and $\mathrm{KCl}$ (Figure 2D). 

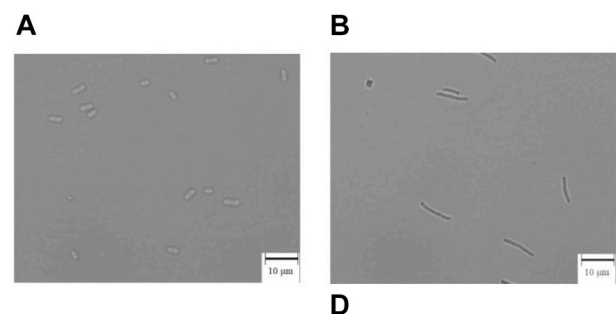

D

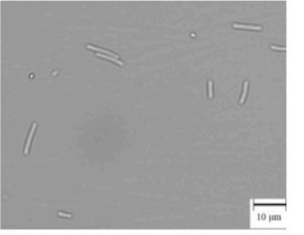

G

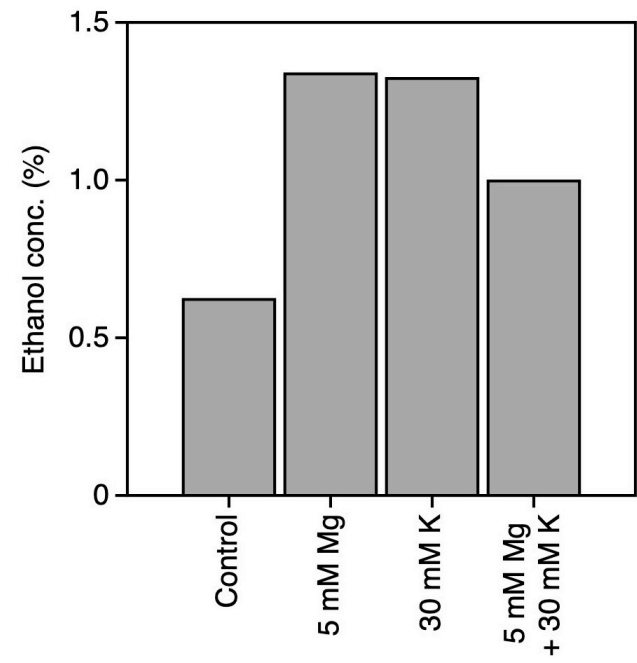

c

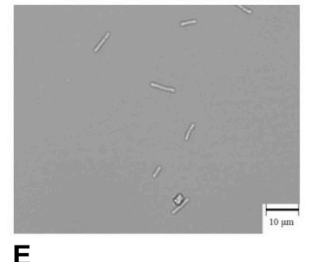

E

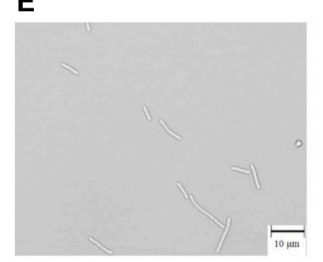

$\mathbf{F}$

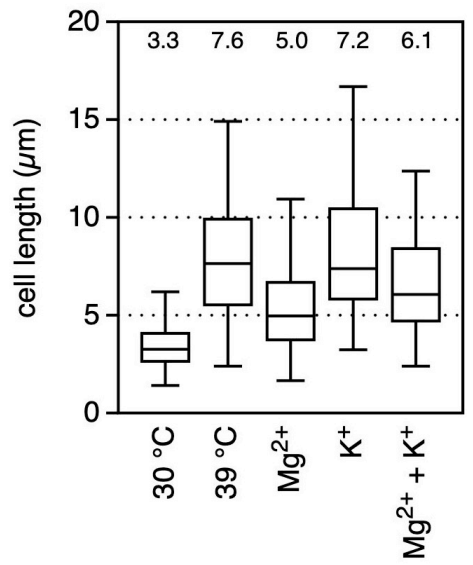

H

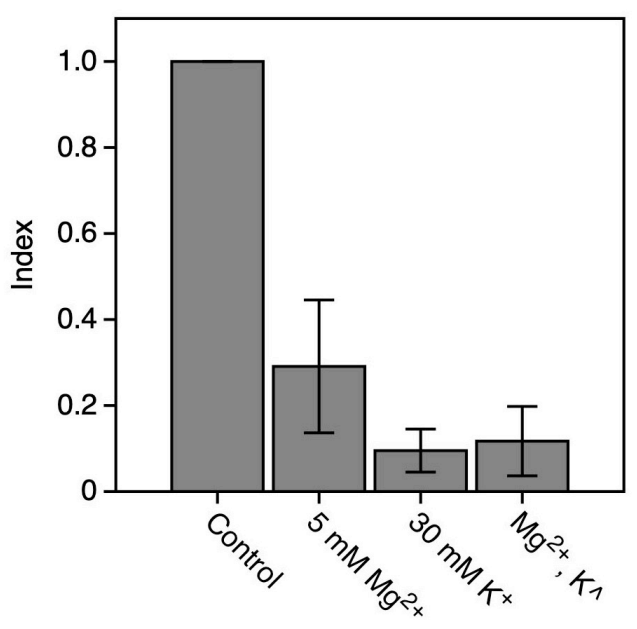

FIGURE 3 | Effects of $\mathrm{Mg}^{2+}$ and $\mathrm{K}^{+}$on the physiology of Zymomonas mobilis TISTR 548 at critical high temperatures. Under all conditions, the final concentrations of the added $\mathrm{MgCl}_{2}$ and $\mathrm{KCl}$ were 5 and $30 \mathrm{mM}$, respectively. (A-E) Morphology of cells grown in $\mathrm{YPD}$ medium at $30^{\circ} \mathrm{C}(\mathbf{A})$ or $39^{\circ} \mathrm{C}$ (B) with $\mathrm{MgCl} 2$ (C), $\mathrm{KCl}(\mathbf{D})$, or both (E) for $7 \mathrm{~h}$ under a static condition. Photographs were taken at a magnification of $\times 400$. Bars indicate $10 \mu \mathrm{m}$. (F) A box plot of cell length from 100 cells measured in these conditions. The median cell length under each condition is shown as a number. (G) Ethanol concentration was measured in culture at $39^{\circ} \mathrm{C}$ for $12 \mathrm{~h}$ in YPD medium under a static condition. (H) The intracellular ROS level was measured in culture at $39^{\circ} \mathrm{C}$ for $12 \mathrm{~h}$. Index was calculated as the ratio of the fluorescence intensity and protein concentration to the values of the control. Values and error bars represent means and standard deviations, respectively, for triplicate experiments.

The results suggested that the optimum concentrations of $\mathrm{MgCl}_{2}$ and $\mathrm{KCl}$ for growth enhancement at $39^{\circ} \mathrm{C}$ were 5 and $30 \mathrm{mM}$, respectively.

\section{Physiological Effects of $\mathrm{Mg}^{2+}$ and $\mathrm{K}^{+}$on Z. mobilis TISTR 548 at CHT}

Our previous report indicated that the cell length of Z. mobilis increased at CHT, and this increase reduced in thermotoleranceenhanced mutants (Kosaka et al., 2019). Indeed, cells grown at $39^{\circ} \mathrm{C}$ had longer cells than those grown at $30^{\circ} \mathrm{C}$, which had granular shapes (Figures 3A,B). Cell morphology observed following the addition of $\mathrm{MgCl}_{2}$ or $\mathrm{KCl}$ indicated that cell length increased, with the increase in cell length being relatively lower following the addition of $\mathrm{Mg}^{2+}$ at $39^{\circ} \mathrm{C}$ than without the addition of metal ions (Figure 3C). On the other hand, the addition of $\mathrm{KCl}$ had no clear effect on cell length at $39^{\circ} \mathrm{C}$, with a predominance of longer filamentous cells (Figure 3D). Cells cultured with both metals showed a mixture of granular and long filamentous shapes (Figure 3E). Indeed, the median value of measured cell length at $30^{\circ} \mathrm{C}$, at $39^{\circ} \mathrm{C}$, with $\mathrm{MgCl}_{2}$ at $39^{\circ} \mathrm{C}$, with $\mathrm{KCl}$ at $39^{\circ} \mathrm{C}$, or with both metals at $39^{\circ} \mathrm{C}$ was $3.3,7.6,5.0,7.2$, or $6.1 \mu \mathrm{m}$, respectively (Figure 3F). Ethanol productivity at $39^{\circ} \mathrm{C}$ was also recovered to be close to the theoretical yield by adding $\mathrm{MgCl}_{2}$ or $\mathrm{KCl}$ (Figure 3G). Accumulation of intracellular ROS was observed in Z. mobilis TISTR 548 at CHT (Kosaka et al., 2019). Addition of $\mathrm{MgCl}_{2}$ or $\mathrm{KCl}$ considerably reduced intracellular ROS levels at $39^{\circ} \mathrm{C}$, and the reduction strength was the highest for only $\mathrm{K}^{+}$, followed by that for both metals and then only $\mathrm{Mg}^{2+}$ (Figure 3H). 


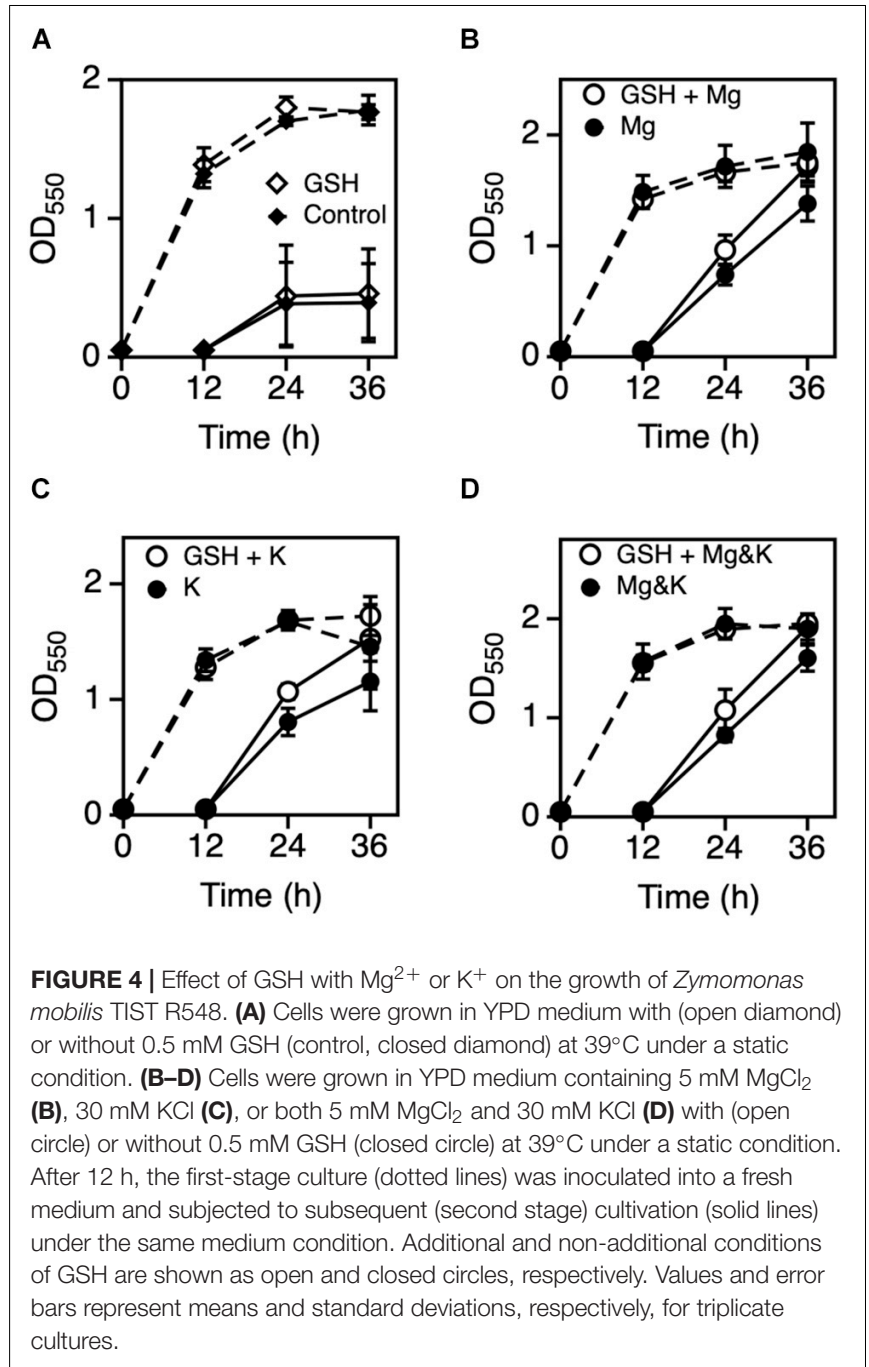

\section{Effects of $\mathrm{Mg}^{2+}$ and $\mathrm{K}^{+}$on Z. mobilis TISTR 548 Growth at CHT}

Previous results indicated that $\mathrm{Mg}^{2+}$ and $\mathrm{K}^{+}$somehow affect the cell physiology of $Z$. mobilis TISTR 548 at CHT and reduce intracellular ROS levels but probably by different mechanisms. Several bacteria use glutathione as a reducing agent to maintain a strongly reducing environment in cells, and glutathione peroxidase is an ROS-scavenging enzyme (Cabiscol Català et al., 2000). We observed the effect of glutathione with $\mathrm{MgCl}_{2}$ or $\mathrm{KCl}$ on cell growth when glutathione was added at several concentrations: $4 \mathrm{mM}$ glutathione inhibited cell growth at $39^{\circ} \mathrm{C}$

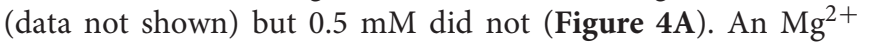
plus glutathione effect was observed, but the effect was not considerably distinct from that observed following the addition of $\mathrm{K}^{+}$or both metals (Figures $4 \mathrm{~B}-\mathrm{D}$ ). Next, an effective concentration of EDTA as a chelator of a divalent cation on cell growth at a CHT were explored, and then effects of metals under the presence of such a concentration of EDTA at a CHT were examined. When $0.05 \mathrm{mM}$ EDTA was added to culture, cell growth was inhibited at $38^{\circ} \mathrm{C}$ (Figure $\mathbf{5 A}$ ). $\mathrm{MgCl}_{2}$ or $\mathrm{KCl}$ was subsequently added under the above condition, and the resulting effect was observed. The addition of $\mathrm{Mg}^{2+}$ rescued EDTA inhibition at CHT (Figure 5B), but that of $\mathrm{K}^{+}$did not (Figure 5C).

\section{Effects of $\mathrm{Mg}^{2+}$ and $\mathrm{K}^{+}$on the Growth of Thermosensitive Mutants}

In a previous study, 26 thermosensitive single gene-disrupted mutants of Z. mobilis TISTR 548 were isolated (Charoensuk et al., 2017). To observe the effects of the addition of $\mathrm{Mg}^{2+}$ and $\mathrm{K}^{+}$on these thermosensitive mutants, their growth upon the addition of each metal was examined. Addition of $\mathrm{Mg}^{2+}$ significantly enhanced the growth of three mutants, whereas it inhibited the growth of one mutant (Table 2). Further, the addition of $\mathrm{K}^{+}$
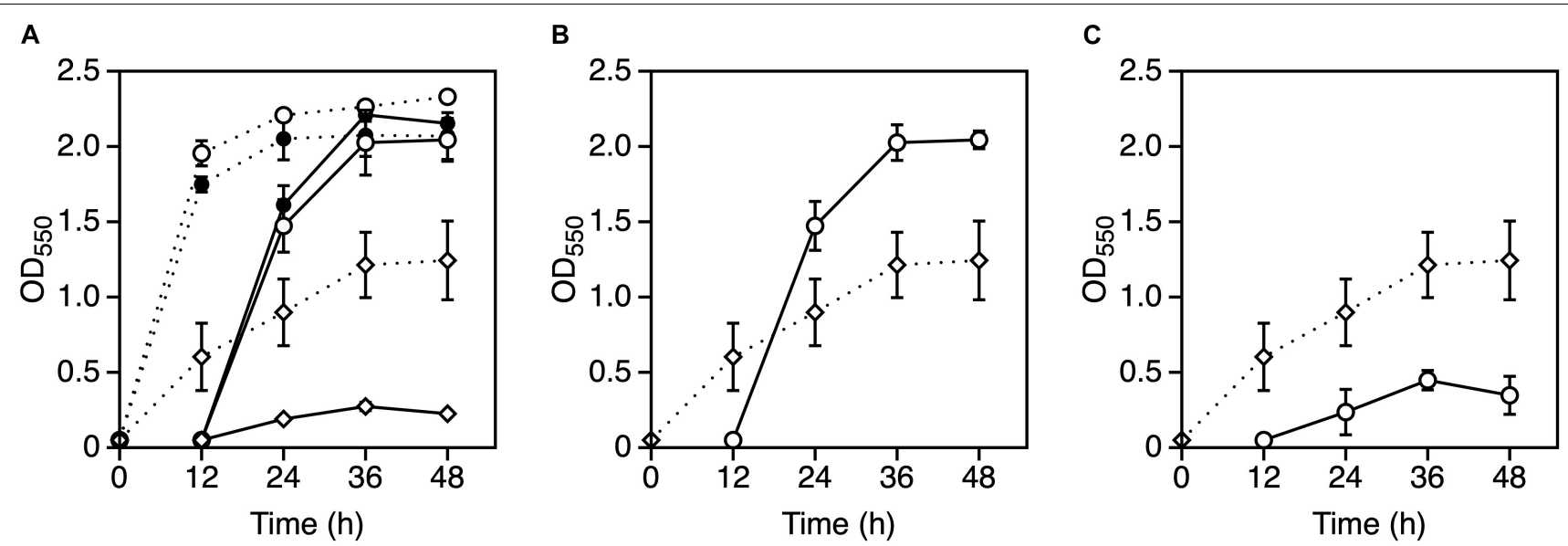

FIGURE 5 | Effect of EDTA with $\mathrm{Mg}^{2+}$ or $\mathrm{K}^{+}$on the growth of Zymomonas mobilis TISTR 548. (A) Cells were subjected to two-step cultivation (dotted line, first; solid line, second) in YPD medium with $0.01 \mathrm{mM}$ EDTA (open circle), $0.05 \mathrm{mM}$ EDTA (open diamond) or without EDTA (closed circle) at $38^{\circ} \mathrm{C}$ under a static condition. (B,C) At the first stage of cultivation, cells were cultured in YPD medium containing $0.05 \mathrm{mM}$ EDTA (open diamond) at $38^{\circ} \mathrm{C}$, and after $12 \mathrm{~h}$, at the second stage of cultivation (open circle), $5 \mathrm{mM} \mathrm{MgCl}_{2}$ (B) or $30 \mathrm{mM} \mathrm{KCl}$ (C) was added to YPD medium containing 0.05 mM EDTA. Values and error bars represent means and standard deviations, respectively, for triplicate cultures. 
TABLE 2 | Effects of $\mathrm{Mg}^{2+}$ and $\mathrm{K}^{+}$on the growth of thermosensitive mutants from Zymomonas mobilis TISTR 548.

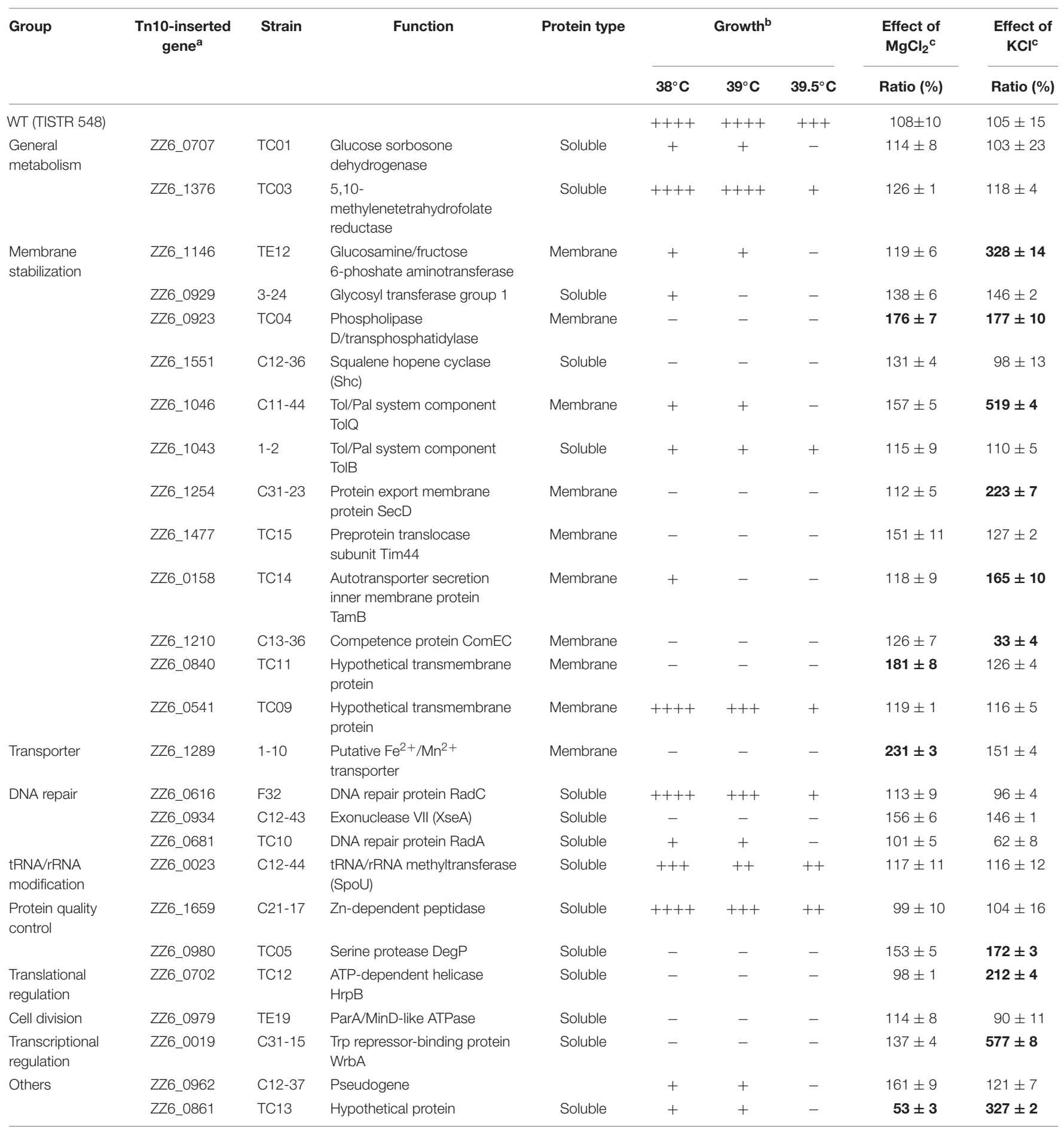

aThirty-six thermotolerant genes were identified, and they were classified into 10 groups (Charoensuk et al., 2017). ${ }^{\mathrm{b}}$ The growth of these mutants at 38,39 , and $39.5^{\circ} \mathrm{C}$ compared with that of the parental strain on YPD medium. The symbols "+" represent the degree of cell growth of mutants at a critical high temperature compared with that of the parental strain, whereas " -" indicates no growth. ${ }^{\circ}$ The ratio (\%) was calculated from the $\mathrm{OD}_{550}$ values for cells grown at $39.5^{\circ} \mathrm{C}$ for $24 \mathrm{~h}$ with $5 \mathrm{mM} \mathrm{MgCl} 2$ or $30 \mathrm{mM} \mathrm{KCl}$ divided by those cells grown without metals. Values represent means \pm standard deviations of three replicates. Bold values indicate a ratio of $>1.5$ or $<0.5$ against the parental strain.

enhanced the growth of nine mutants, i.e., almost one-third of all thermosensitive mutants, but it inhibited the growth of one mutant (C13-36) at $39.5^{\circ} \mathrm{C}$ (Table 2). Remarkably, the addition of both $\mathrm{Mg}^{2+}$ and $\mathrm{K}^{+}$enhanced the growth of only one mutant with gene encoding for phospholipase $\mathrm{D}$; they had the opposite effect on the mutant TC13 (Table 2). These results also suggest 


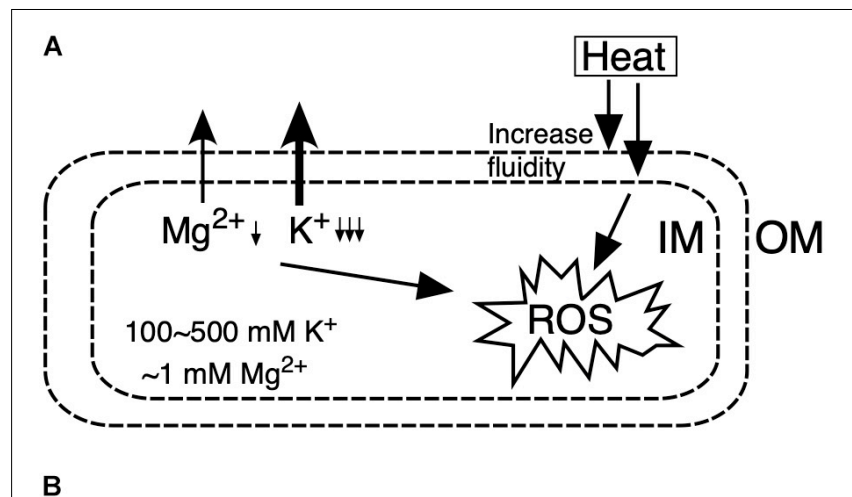

B

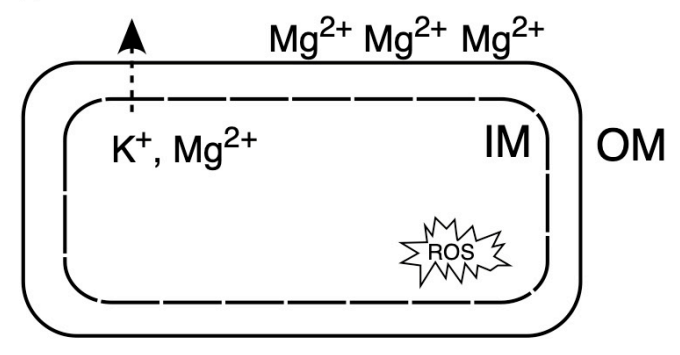

C

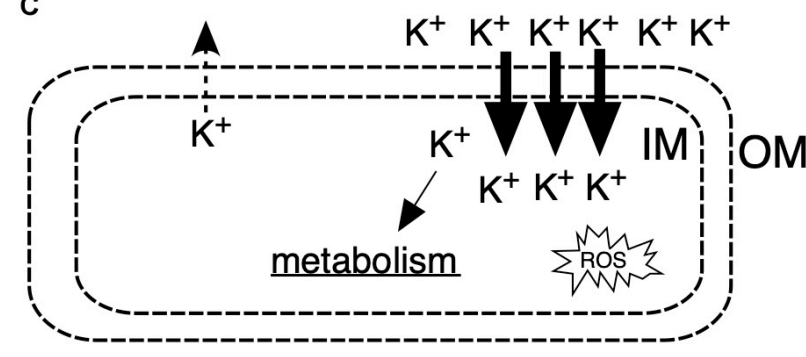

FIGURE 6 | Models for the action mechanisms of $\mathrm{Mg}^{2+}$ and $\mathrm{K}^{+}$on Z. mobilis TISTR 548 at CHT. (A) Under CHT conditions, (B) by the addition of $\mathrm{Mg}^{2+}$, (C) by the addition of $\mathrm{K}^{+}$. IM, inner membrane; OM, outer membrane; ROS, reactive oxygen species.

that $\mathrm{Mg}^{2+}$ and $\mathrm{K}^{+}$affect the cell physiology of Z. mobilis TISTR 548 differently at $\mathrm{CHT}$.

\section{DISCUSSION}

We observed the additional effects of $\mathrm{Ni}^{2+}, \mathrm{Zn}^{2+}, \mathrm{Fe}^{3+}, \mathrm{Al}^{3+}$, $\mathrm{Mn}^{2+}$, and $\mathrm{Co}^{2+}$ on Z. mobilis TISTR 548 growth at high temperatures, but these metals showed only negative effects (Figure 1). Among these, the effects of $\mathrm{Fe}^{3+}$ and $\mathrm{Al}^{3+}$ were negligible under the tested conditions (Figures 1E-H). However, $1.0 \mathrm{mM} \mathrm{Ni}{ }^{2+}, \mathrm{Zn}^{2+}, \mathrm{Mn}^{2+}$, and $\mathrm{Co}^{2+}$ clearly inhibited $Z$. mobilis TISTR 548 growth (Figure 1). A previous report indicated that the addition of $0.35 \mathrm{mM} \mathrm{Zn}^{2+}$ markedly inhibited ethanol productivity in Z. mobilis ZM4 probably by inhibiting metabolic enzymes (Liu et al., 2010). In the case of a different microorganism, i.e., S. cerevisiae, the quantity of $\mathrm{Zn}^{2+}, \mathrm{Mg}^{2+}$, and $\mathrm{Mn}^{2+}$ required for effective fermentation was $0.01,0.05$, and $0.04 \mathrm{~g} / \mathrm{L}$, respectively (Deesuth et al., 2012), implying that $0.1 \mathrm{mM}$ metals are usually required for growth, but excess concentrations can inhibit growth. This implies that only specific metals enhance the growth of specific microorganisms.

Only $\mathrm{Mg}^{2+}$ and $\mathrm{K}^{+}$enhanced Z. mobilis TISTR 548 growth and improved $\mathrm{CHT}$ from 38 to $39^{\circ} \mathrm{C}$ (Figure 2A). At CHT, the intracellular molecular components of bacterial cells leaked (Haight and Morita, 1966; Allwood and Russell, 1967). In S. cerevisiae and probably other microorganisms, the addition of $\mathrm{K}^{+}$prevents ion leakage (Lam et al., 2014). $\mathrm{K}^{+}$channels are activated when tension in the lipid bilayer is increased (Iwamoto and Oiki, 2018), and $\mathrm{Mg}^{2+}$ transporters are induced by heat treatment in Salmonella enterica (O'Connor et al., 2009). Regarding quantity, these two metal ions $\left(\mathrm{K}^{+}\right.$and $\mathrm{Mg}^{2+}$ ) are the principal and second highest ions in bacterial cells found at concentrations of $100-500 \mathrm{mM}$ (Ballal et al., 2007) and $\sim 1 \mathrm{mM}$ (Groisman et al., 2013), respectively. Therefore, the optimal concentrations of $30 \mathrm{mM} \mathrm{K}^{+}$and $5 \mathrm{mM} \mathrm{Mg}^{2+}$ (Figures 2A,B) are probably related to their intracellular concentrations, further suggesting that similar ion conditions enhance cell metabolism by preventing ion leakage from cells or supporting ion transportation from the extracellular space. However, the effects of $\mathrm{Mg}^{2+}$ and $\mathrm{K}^{+}$on the two common characteristics of bacteria, namely, cell elongation and ROS accumulation, observed in Z. mobilis TISTR 548 at CHT (Matsushita et al., 2016) were different. Cell length at CHT was suppressed by the addition of $\mathrm{Mg}^{2+}$ but not by that of $\mathrm{K}^{+}$(Figure 3F). Although ROS accumulation reduced by the addition of both metals, the addition of $\mathrm{K}^{+}$showed a stronger effect than that of $\mathrm{Mg}^{2+}$ (Figure 3H). The GSH results indicated that the additive effect of GSH was observed in both cases of $\mathrm{Mg}^{2+}$ and $\mathrm{K}^{+}$(Figures 4B,C), suggesting that the growth enhancement effect of $\mathrm{Mg}^{2+}$ or $\mathrm{K}^{+}$does not arise directly from the action of GSH added exogenously. In a Gram-negative bacterium, E. coli, GSH is important for periplasmic redox homeostasis (Pittman et al., 2005) and heterogeneous expression of glutathione reductase allows the microbe to be hydrogen peroxide tolerance (Kim et al., 2009). It is assumed that, in Z. mobilis TISTR 548, GSH keeps periplasmic redox homeostasis and/or somehow makes cells tolerate oxidative stress by its reducing power, but the major effects at $\mathrm{CHT}$ by $\mathrm{Mg}^{2+}$ and $\mathrm{K}^{+}$ are not likely the action by GSH. Moreover, EDTA treatment showed that $\mathrm{K}^{+}$did not complement the EDTA effect at CHT (Figure 5C). These results suggest that $\mathrm{Mg}^{2+}$ and $\mathrm{K}^{+}$affect the cell physiology of Z. mobilis TISTR 548 at CHT using different mechanisms.

The effect of $\mathrm{Mg}^{2+}$ on the cell physiology of $Z$. mobilis TISTR 548 at $\mathrm{CHT}$ has been described: $\mathrm{Mg}^{2+}$ probably stabilizes membrane structure as proposed in E. coli (Charoensuk et al., 2017). $\mathrm{Mg}^{2+}$ stabilizes OM (Nikaido and Vaara, 1985), particularly LPS, where $\mathrm{Mg}^{2+}$ bridges lipid A (Nikaido, 2003). The present study results also showed that the addition of $\mathrm{Mg}^{2+}$ repressed cell elongation at CHT (Figure 3F) and restored the growth of the disrupted genes of ZZ6_0923, which encodes the cardiolipin biosynthesis protein (Table 2). However, $\mathrm{Mg}^{2+}$ has been thought to stabilize proteins, enhance protein-nucleic acid interactions, mitigate oxidative stress, and act as a metabolic signal (O'Connor et al., 2009). $\mathrm{Mg}^{2+}$ is required 
to maintain cell metabolism, DNA replication, transcription and translation, and DNA stabilization (Xu et al., 2018), and it plays a role in enzyme activations. For instance, $\mathrm{Mg}^{2+}$ stabilizes pyruvate decarboxylase, an enzyme responsible for the decarboxylation of pyruvate in central metabolism, with thiamine diphosphate serving as a cofactor (Pohl et al., 1994). Besides, phosphoglycerate kinase uses $\mathrm{Mg}^{2+}$ as a cofactor (Andreini et al., 2008). Addition of $\mathrm{Mg}^{2+}$ reduced ROS accumulation at $\mathrm{CHT}$ (Figure 3H), and the growth of the disrupted $\mathrm{Fe}^{2+} / \mathrm{Mn}^{2+}$ transporter (ZZ6_1289) recovered greatly (Table 2). Therefore, maintaining an intracellular $\mathrm{Mg}^{2+}$ concentration may enable heat tolerance either by ions or cytoplasmic $\mathrm{Mg}^{2+}$ sensors, proteins, and RNAs. (Groisman et al., 2013).

$\mathrm{K}^{+}$, the most dominant intracellular cation, greatly contributes to $\mathrm{pH}$ homeostasis and turgor maintenance as well as bacterial osmotic adaptation, $\mathrm{pH}$ regulation, gene expression, and cell enzyme activation (Epstein, 2003; Ballal et al., 2007). Indeed, the addition of $\mathrm{K}^{+}$affected most cell physiology of $Z$. mobilis TISTR 548 at CHT (Table 2), e.g., the growth of 35\% (9/26 strains) of mutants recovered greatly. These effects may contribute to reducing intracellular ROS levels (Figure $3 \mathbf{H}$ ). Between these, $\mathrm{K}^{+}$probably facilitates the functioning of periplasmic proteins in $Z$. mobilis TISTR 548 due to the growth recovery of disrupted $\operatorname{tol} Q, \sec D, \operatorname{tam} B$, and $\operatorname{deg} P$ (Table 2). The amount of intracellular $\mathrm{K}^{+}$directly affects membrane potential (Bakker and Mangerich, 1981), which is required for protein secretion to periplasm (Daniels et al., 1981). The membrane potential is hypothetically required for potassium transport from extracellular space to the cytoplasm via the membrane potentialdriven $\mathrm{K}^{+}$uptake system (Kup, ZMO1209, and ZZ6_0125) in Z. mobilis. Therefore, $\mathrm{K}^{+}$may also facilitate membrane potential maintenance in $Z$. mobilis TISTR 548.

Under CHT conditions (Figure 6A), the inner membrane fluidity increases to cause leakages of ions from cytoplasm and electrons from the respiratory chain, which lead to the accumulation of intracellular reactive oxygen species, resulting in damage of macromolecules of DNA, RNA, proteins and lipids, and thereby cells are elongated and unable to maintain intracellular homeostasis, causing cell death. However, by the addition of $\mathrm{Mg}^{2+}$ (Figure 6B), the $\mathrm{OM}$ is stabilized by binding of $\mathrm{Mg}^{2+}$ and the inner membrane is also stabilized, resulting in suppression of the leakage of intracellular ions as well as the leakage of electrons from the respiratory chain. On the other hand, by the addition of $\mathrm{K}^{+}$(Figure 6C), $\mathrm{K}^{+}$leakage is repressed to maintain homeostasis for cellular metabolism, by which intracellular ROS is reduced. Moreover, these observations suggest that $\mathrm{Mg}^{2+}$ and $\mathrm{K}^{+}$exhibit diverse, rather than single, effects on $Z$. mobilis TISTR 548. Interestingly, when both $\mathrm{Mg}^{2+}$

\section{REFERENCES}

Abdel-Banat, B. M., Hoshida, H., Ano, A., Nonklang, S., and Akada, R. (2010). High-temperature fermentation: how can processes for ethanol production at high temperatures become superior to the traditional process using mesophilic yeast. Appl. Microbiol. Biotechnol. 85, 861-867. doi: 10.1007/s00253-0092248-5 and $\mathrm{K}^{+}$exist in the medium at high concentrations, their crosstalk effects on cell physiology sometimes occur. These effects are partly specific to each ion; their additive effect on cell growth at CHT was observed, but that did not entail the whole sum of their effects (Figure 2C). The thermotolerance acquisition mechanisms of $Z$. mobilis upon the addition of $\mathrm{Mg}^{2+}$ and $\mathrm{K}^{+}$ are more complex than the accumulated effects of their metals in accomplishing enhanced $Z$. mobilis growth at $\mathrm{CHT}$.

\section{CONCLUSION}

Among various metals, only $\mathrm{Mg}^{2+}$ and $\mathrm{K}^{+}$enhanced the thermotolerance of $Z$. mobilis TISTR 548. The primary effects of $\mathrm{Mg}^{2+}$ and $\mathrm{K}^{+}$on the cell physiology of Z. mobilis TISTR 548 are largely different, but these metals reduce intracellular ROS accumulation. Based on the study results, several strategies for improving the $\mathrm{CHT}$ of $Z$. mobilis by membrane stabilization and intracellular metabolism maintenance can be expected. Further research is needed to reveal these mechanisms for improving its growth at CHT.

\section{DATA AVAILABILITY STATEMENT}

All datasets generated for this study are included in the article/supplementary material.

\section{AUTHOR CONTRIBUTIONS}

AN, TS, KM, and SA conducted the experiments. TK, AN, TS, $\mathrm{KM}$, and MY analyzed the data. TK, AN, and MY wrote the manuscript. All authors conceived this study.

\section{FUNDING}

This study was conducted under the JPMJAL1106 Project of the Advanced Low Carbon Technology Research and Development Program (ALCA) funded by the Japan Science and Technology Agency (JST) (TK and MY).

\section{ACKNOWLEDGMENTS}

We thank Kazunobu Matsushita, Toshiharu Yakushi, and Naoya Kataoka of Yamaguchi University for their helpful discussions.

Aldiguier, A. S., Alfenore, S., Cameleyre, X., Goma, G., Uribelarrea, J. L., Guillouet, S. E., et al. (2004). Synergistic temperature and ethanol effect on Saccharomyces cerevisiae dynamic behaviour in ethanol bio-fuel production. Bioprocess Biosyst. Eng. 26, 217-222. doi: 10.1007/s00449-004-0352-6

Allwood, M. C., and Russell, A. D. (1967). Mechanism of thermal injury in Staphylococcus aureus: I. relationship between viability and leakage. Appl. Microbiol. 15, 1266-1269. doi: 10.1128/aem.15.6.1266-1269.1967 
Andreini, C., Bertini, I., Cavallaro, G., Holliday, G. L., and Thornton, J. M. (2008). Metal ions in biological catalysis: from enzyme databases to general principles. J. Biol. Inorg. Chem. 13, 1205-1218. doi: 10.1007/s00775-008-0404-5

Bakker, E. P., and Mangerich, W. E. (1981). Interconversion of components of the bacterial proton motive force by electrogenic potassium transport. J. Bacteriol. 147, 820-826. doi: 10.1128/jb.147.3.820-826.1981

Ballal, A., Basu, B., and Apte, S. K. (2007). The Kdp-ATPase system and its regulation. J. Biosci. 32, 559-568. doi: 10.1007/s12038-007-0055-7

Cabiscol Català, E., Tamarit Sumalla, J., and Ros Salvador, J. (2000). Oxidative stress in bacteria and protein damage by reactive oxygen species. Int. Microbiol. 3, 3-8.

Charoensuk, K., Sakurada, T., Tokiyama, A., Murata, M., Kosaka, T., Thanonkeo, P., et al. (2017). Thermotolerant genes essential for survival at a critical high temperature in thermotolerant ethanologenic Zymomonas mobilis TISTR 548. Biotechnol. Biofuels 10:204. doi: 10.1186/s13068-017-0891-0

Chisti, Y. (2008). Biodiesel from microalgae beats bioethanol. Trends Biotechnol. 26, 126-131. doi: 10.1016/j.tibtech.2007.12.002

Daniels, C. J., Bole, D. G., Quay, S. C., and Oxender, D. L. (1981). Role for membrane potential in the secretion of protein into the periplasm of Escherichia coli. Proc. Natl. Acad. Sci. U.S.A. 78, 5396-5400. doi: 10.1073/pnas.78.9.5396

Deesuth, O., Laopaiboon, P., Jaisil, P., and Laopaiboon, L. (2012). Optimization of nitrogen and metal ions supplementation for very high gravity bioethanol fermentation from sweet sorghum juice using an orthogonal qray design. Energies 5, 3178-3197. doi: 10.3390/en5093178

Dulley, J. R., and Grieve, P. A. (1975). A simple technique for eliminating interference by detergents in the Lowry method of protein determination. Anal. Biochem. 64, 136-141. doi: 10.1016/0003-2697(75)90415-7

Epstein, W. (2003). The roles and regulation of potassium in bacteria. Prog. Nucleic Acid Res. Mol. Biol. 75, 293-320. doi: 10.1016/s0079-6603(03)75008-9

Gadd, G. M. (1992). Metals and microorganisms: a problem of definition. FEMS Microbiol. Lett. 100, 197-203. doi: 10.1111/j.1574-6968.1992.tb14040.x

Groisman, E. A., Hollands, K., Kriner, M. A., Lee, E. J., Park, S. Y., and Pontes, M. H. (2013). Bacterial $\mathrm{Mg}^{2+}$ homeostasis, transport, and virulence. Annu. Rev. Genet. 47, 625-646. doi: 10.1146/annurev-genet-051313-051025

Hahn-Hägerdal, B., Galbe, M., Gorwa-Grauslund, M. F., Lidén, G., and Zacchi, G. (2006). Bio-ethanol-the fuel of tomorrow from the residues of today. Trends Biotechnol. 24, 549-556. doi: 10.1016/j.tibtech.2006.10.004

Haight, R. D., and Morita, R. Y. (1966). Thermally induced leakage from Vibrio marinus, an obligately psychrophilic marine bacterium. J. Bacteriol. 92, 13881393. doi: $10.1128 / \mathrm{jb}$.92.5.1388-1393.1966

He, M. X., Wu, B., Qin, H., Ruan, Z. Y., Tan, F. R., Wang, J. L., et al. (2014). Zymomonas mobilis: a novel platform for future biorefineries. Biotechnol. Biofuels 7, 101. doi: 10.1186/1754-6834-7-101

Huang, S., and Chen, X. D. (2013). Significant effect of Ca2+ on improving the heat resistance of lactic acid bacteria. FEMS Microbiol. Lett. 344, 31-38. doi: $10.1111 / 1574-6968.12151$

Iwamoto, M., and Oiki, S. (2018). Constitutive boost of a $\mathrm{K}^{+}$channel via inherent bilayer tension and a unique tension-dependent modality. Proc. Natl. Acad. Sci. U.S.A. 115, 13117-13122. doi: 10.1073/pnas.1812282115

Kim, I. S., Shin, S. Y., Kim, Y. S., Kim, H. Y., and Yoon, H. S. (2009). Expression of a glutathione reductase from Brassica rapa subsp. pekinensis enhanced cellular redox homeostasis by modulating antioxidant proteins in Escherichia coli. Mol. Cells 28, 479-487. doi: 10.1007/s10059-009-0168-y

Kosaka, T., Lertwattanasakul, N., Rodrussamee, N., Nurcholis, M., Dung, N. T. P., Keo-Oudone, C., et al. (2018). "Potential of thermotolerant ethanologenic yeasts isolated from ASEAN countries and their application for high temperature fermentation," in Fuel Ethanol Production from Sugarcane, eds T. P. Basso, and L. C. Basso, (London: IntechOpen), 121-154.

Kosaka, T., Nakajima, Y., Ishii, A., Yamashita, M., Yoshida, S., Murata, M., et al. (2019). Capacity for survival in global warming: adaptation of mesophiles to the temperature upper limit. PLoS One 14:e0215614. doi: 10.1371/journal.pone. 0215614

Lam, F. H., Ghaderi, A., Fink, G. R., and Stephanopoulos, G. (2014). Biofuels. Engineering alcohol tolerance in yeast. Science 346, 71-75. doi: 10.1126/science. 1257859
Liu, C., Dong, H., Zhong, J., Ryu, D. D., and Bao, J. (2010). Sorbitol production using recombinant Zymomonas mobilis strain. J. Biotechnol. 148, 105-112. doi: 10.1016/j.jbiotec.2010.04.008

Matsushita, K., Azuma, Y., Kosaka, T., Yakushi, T., Hoshida, H., Akada, R., et al. (2016). Genomic analyses of thermotolerant microorganisms used for hightemperature fermentations. Biosci. Biotechnol. Biochem. 80, 655-668. doi: 10. 1080/09168451.2015.1104235

Murata, M., Fujimoto, H., Nishimura, K., Charoensuk, K., Nagamitsu, H., Raina, S., et al. (2011). Molecular strategy for survival at a critical high temperature in Escherichia coli. PLoS One 6:e20063. doi: 10.1371/journal.pone.0020063

Murata, M., Nitiyon, S., Lertwattanasakul, N., Sootsuwan, K., Kosaka, T., Thanonkeo, P., et al. (2015). High-temperature fermentation technology for low-cost bioethanol. J. Jap. Inst. Energy 94, 1154-1162. doi: 10.3775/jie.94.1154

Nikaido, H. (2003). Molecular basis of bacterial outer membrane permeability revisited. Microbiol. Mol. Biol. Rev. 67, 593-656. doi: 10.1128/mmbr.67.4.593656.2003

Nikaido, H., and Vaara, M. (1985). Molecular basis of bacterial outer membrane permeability. Microbiol. Rev. 49, 1-32. doi: 10.1128/mmbr.49.1.1-32.1985

O'Connor, K., Fletcher, S. A., and Csonka, L. N. (2009). Increased expression of $\mathrm{Mg}^{2+}$ transport proteins enhances the survival of Salmonella enterica at high temperature. Proc. Natl. Acad. Sci. U.S.A. 106, 17522-17527. doi: 10.1073/pnas. 0906160106

Panesar, P. S., Marwaha, S. S., and Kennedy, J. F. (2006). Zymomonas mobilis: an alternative ethanol producer. J. Chem. Technol. Biotechnol. 81, 623-635. doi: $10.1002 /$ jctb. 1448

Pittman, M. S., Robinson, H. C., and Poole, R. K. (2005). A bacterial glutathione transporter (Escherichia coli CydDC) exports reductant to the periplasm. J. Biol. Chem. 280, 32254-32261. doi: 10.1074/jbc.m503075200

Pohl, M., Grötzinger, J., Wollmer, A., and Kula, M. (1994). Reversible dissociation and unfolding of pyruvate decarboxylase from Zymomonas mobilis. Eur. J. Biochem. 224, 651-661. doi: 10.1111/j.1432-1033.1994. 0651a.x

Reid, D. W., O’May, C., Roddam, L. F., and Lamont, I. L. (2009). Chelated iron as an anti-Pseudomonas aeruginosa biofilm therapeutic strategy. J. Appl. Microbiol. 106:1058. doi: 10.1111/j.1365-2672.2008.03955.x

Schneider, C. A., Rasband, W. S., and Eliceiri, K. W. (2012). NIH Image to ImageJ: 25 years of image analysis. Nat. Methods 9, 671-675. doi: 10.1038/nmeth.2089

Sootsuwan, K., Irie, A., Murata, M., Lertwattanasakul, N., Thanonkeo, P., and Yamada, M. (2007). Thermotolerant Zymomonas mobilis: comparison of ethanol fermentation capability with that of an efficient type strain. Open Biotechnol. J. 1, 59-65. doi: 10.2174/1874070700701010059

Thanonkeo, P., Laopaiboon, P., Sootsuwan, K., and Yamada, M. (2007). Magnesium ions improve growth and ethanol production of Zymomonas mobilis under heat or ethanol stress. Biotechnology 6, 112-119. doi: 10.3923/ biotech.2007.112.119

Xu, E., Wu, Z., Jiao, A., and Jin, Z. (2018). Effect of exogenous metal ions and mechanical stress on rice processed in thermal-solid enzymatic reaction system related to further alcoholic fermentation efficiency. Food Chem. 240, 965-973. doi: 10.1016/j.foodchem.2017.08.033

Yang, Y., Huang, S., Wang, J., Jan, G., Jeantet, R., and Chen, X. D. (2017). $\mathrm{Mg}^{2+}$ improves the thermotolerance of probiotic Lactobacillus rhamnosus GG, Lactobacillus casei Zhang and Lactobacillus plantarum P-8. Lett. Appl. Microbiol. 64, 283-288. doi: 10.1111/lam.12716

Conflict of Interest: The authors declare that the research was conducted in the absence of any commercial or financial relationships that could be construed as a potential conflict of interest.

Copyright (๔ 2020 Kosaka, Nishioka, Sakurada, Miura, Anggarini and Yamada. This is an open-access article distributed under the terms of the Creative Commons Attribution License (CC BY). The use, distribution or reproduction in other forums is permitted, provided the original author(s) and the copyright owner(s) are credited and that the original publication in this journal is cited, in accordance with accepted academic practice. No use, distribution or reproduction is permitted which does not comply with these terms. 